COMPLETE APHONIA OF NEARLY FIVE YEARS' STANDING, CURED BY THE REPEATED APPLICATION OF FARADI-
SATION TO THE VOCAL CORDS.

BY ROBERT TORRANCE, L.R.C.P. EDIN., STRGEON TO THE NEWCASTLE-ON-TYNE THROAT AND EAR INFIRMARY.

Mrss A.P_, aged twenty-four, consulted me in October, 1SS0, for loss of voice of nearly five years' standing. She looked delicate, but did not complain of weakness, and informed me that she had had an ulcerated sore-throat, and lost her voice on leaving a heated room in November, 1875. On recovering from the sore-throat, her voice did not return, when the regular medical attendant applied caustic two or three times, but without any beneficial effect. She then consulted several eminent practitioners, and amongst them a leading physician in Dublin, who recommended galvanism to be applied by means of a battery, but the result was the same as before. Preparatory to my making a laryngoscopic examination, it may be stated that the fact was proved that the loss of function was not due to hysteria, as she was placed completely under the influence of chloroform, when she did not speak, but continued to whisper. The instrument then showed that the vocal cords were in a very relaxed state, and crumpled up as it were near their middle, but otherwise apparently quite healthy, and galvanism seemed clearly indicated in the case. It was therefore strongly recommended to apply it for some time by one of Pulvermacher's chains, but this failed, when it was continued by means of a metallic brush for a much longer period, but there was not the least return of the voice. Knowing that the alternation of topical remedies often proved efficacious in the treatment of chronic inflammation of mucous passages, they were prescribed during the whole of this time, but neither of them, combined with the former, produced any good effect. The cords were then faradised by means of Mackenzie's electrode, when after very few applications of the electro-magnetic current the voice was partly restored, but as a very harsh "croak" at first, and very monotonous. She was asked to sing over a scale of music, but every note was pronounced in the same tone, and she could not modulate her voice either piano or fortissimo. After the current had been repeated at gradually lengthening intervals, however, the voice was permanently restored, and now she speaks in a clear and natural tone, which had been lost for nearly five years. She was seen a few weeks ago, and I heard from her own lips that the cure had been permanent.

Remarks. - This patient, anxious to regain her voice, had previously given everything prescribed for her, both local and constitutional, a fair trial. Tonics and zine pills were persevered in for a very long time, as well as the inhalation of vapours impregnated with different volatile principles. Powders were introduced by insufflation, and this again followed by various escharotics, but without the least benefit resulting until the vocal cords were faradised, which proved there had been no structural disease, but that the case resolved itself into one of functional aphonia or vocal weakness. The case requires no further comment, but the superiority of the internal method of faradisation must certainly beadmitted. Newcastle-on-Tyne.

\section{CASE OF ENTERO-EPIPLOCELE; OPERATION AND RECOVERY.}

\section{BY J. NOBLE BREDIN, L.R.C.S.I., \&c.}

Ox Sept. 4th I was sent for to see a man aged fifty-seven, of rery robust constitution. On examination $I$ found a swelling in the right groin, hard, without fluctuation, and with comparatively little tenderness. Having learned that a small nodule had been there several years, it at once occurred to me this was an enlarged gland brought on by orerwork, patient being a hop dryer, and hopping just then being in full swing. He was now about resuming his occupation. I ordered him to bed, and he obeyed after much remonstrance. No history of anything coming on suddenly. Alli could learn was that the swelling became larger four days previously. I then concluded it wasa femoral hernia, and tried the taxis, using much caution, but without effect. At 6 P.M. the same evening I put him under the influence of chloroform after a prolonged struggle, at the same time being very careful as to manipulative measures, feeling, I must confess, rather dubious about the case. This was also without success. On the following morning patient did not seem any worse. During the time that had elapsed, now five days, no sickness, no hiccough, not even a bad symptom showed itself to give a clue to the case. I now obtained the assistance of Mr. Harris, surgeon to the West Kent Hospital, Maidstone, who fully concurred in all that was done.

We forthwith placed him under the influence of bichloride of methylene, although I must say I look on this anæsthetic as being far inferior to chloroform. Our patient inhaled a very large quantity before complete insensibility supervened. Manipulative measures were again tried, but in vain. Lister's operation was then performed, and after dividing the constricting tissues no reduction could be effected. The sac was now opened. We then found the omentum had been pushed down before the intestine. This was ligatured about half an inch from the end, cutting off the omentum, reduction taking place immediately. The wound being stitched and a bandage applied, I gave him a quarter of a grain of morphia, with directions to repeat the dose in four hours, also one tablespoonful of brandy in milk every three hours, together with beef-tea in the interim. Patient passed a good night very comfortable and free from pain. I saw him four times next day to watch the effects of the morphia, which I still continued. Patient went on without interrup. tion, not an untoward symptom or even any pain, still going on with the morphia at intervals, until the expiration of seven days. The bowels not being relieved, I ordered two teaspoonfuls of castor oil every two hours ad effectum. This produced a very decided change for the better, the motions being perfectly natural, and passed without pain. On the eighth day I ordered him one pint of stout daily, directing his wife to send each day to my house for some dinner, to which he did ample justice, together with one pint of bitter beer. Wound healing and looking healthy. Dressed with carbolic acid ( 1 to 20). He was up and about with a truss in forty-six days after the operation.

Remarks. - Morphia seemed to me to be the sheet anchor in this case, equalising the system, thereby preventing all pain, and keeping all inflammatory action in submission. Consequently no sickness or nausea occurred, such as I have seen follow from methylene.

Chart Sutton, Staplehurst.

\section{d thtirtor}

\section{HOSPITAL PRACTICE, BRITISH AND FOREIGN.}

Nulla autem est alia pro certo noscendi via, nisi quamplurimas et morborum et dissectiorum historias, tum aliorum tum proprias collectas habere, et inter se comparare.-Morgagm De Sed. et Caus. Morb., lib. iv. Procmium.

\section{ST. GEORGE'S HOSPITAL. \\ [SkIN DEPARTMENT.]}

CASE OF BROMIDF ERUPTION.

(Under the care of Dr. CAVAFY.)

THE following notes were taken by Mr. Alexander, clinical clerk.

Edward B-, aged fourteen months, was first seen at the hospital on March 17th, 1881. The child had whoopingcough, from which, according to the mother, he had suffered for five months. Six weeks before he was attacked with convulsions, which were at first very frequent. They gradually diminished and subsided in a fortnight under treatment by bromide of potassium, which the mother stated was at once ordered by the medical man who saw the child, and continued for a week after the fits had ceased. Various medicines had been given for the whooping.cough, and the last prescription (which the mother brought with her) contained bromide of potassium, tincture of belladonna, and juice of conium. The daily dose of bromide contained in this last mixture was four grains, and the medicine had been 